\title{
Evidence for Elevation-Dependent Warming in the St. Elias Mountains, Yukon, Canada
}

\author{
Scott N. Williamson, ${ }^{\mathrm{a}}$ Christian Zdanowicz, ${ }^{\mathrm{b}}$ FAROn S. Anslow, ${ }^{\mathrm{c}}$ GARry K. C. Clarke, ${ }^{\mathrm{d}}$ \\ Luke COPland, ${ }^{a}$ RYAn K. DANby, ${ }^{\mathrm{e}}$ GWENn E. Flowers, ${ }^{\mathrm{f}}$ GERALD HOLDSWORTh, ${ }^{\mathrm{g}}$ \\ ALEXANDER H. JAROSCH, ${ }^{\mathrm{h}}$ AND DAVID S. HIK ${ }^{\mathrm{i}}$

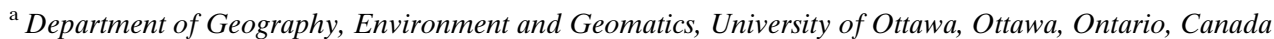 \\ ${ }^{\mathrm{b}}$ Department of Earth Sciences, Uppsala University, Uppsala, Sweden \\ ${ }^{c}$ Pacific Climate Impacts Consortium, University of Victoria, Victoria, British Columbia, Canada \\ ${ }^{\mathrm{d}}$ Department of Earth, Ocean and Atmospheric Sciences, The University of British Columbia, Vancouver, \\ British Columbia, Canada \\ ${ }^{\mathrm{e}}$ Department of Geography and Planning, Queen's University, Kingston, Ontario, Canada \\ ${ }^{\mathrm{f}}$ Department of Earth Sciences, Simon Fraser University, Burnaby, British Columbia, Canada \\ ${ }^{\mathrm{g}}$ Arctic Institute of North America, University of Calgary, Calgary, Alberta, Canada \\ ${ }^{\mathrm{h}}$ Kufstein, Austria \\ ${ }^{i}$ Department of Biological Sciences, Simon Fraser University, Burnaby, British Columbia, Canada
}

(Manuscript received 7 June 2019, in final form 16 January 2020)

\begin{abstract}
The climate of high midlatitude mountains appears to be warming faster than the global average, but evidence for such elevation-dependent warming (EDW) at higher latitudes is presently scarce. Here, we use a comprehensive network of remote meteorological stations, proximal radiosonde measurements, downscaled temperature reanalysis, ice cores, and climate indices to investigate the manifestation and possible drivers of EDW in the St. Elias Mountains in subarctic Yukon, Canada. Linear trend analysis of comprehensively validated annual downscaled North American Regional Reanalysis (NARR) gridded surface air temperatures for the years 1979-2016 indicates a warming rate of $0.028^{\circ} \mathrm{C} \mathrm{a}^{-1}$ between 5500 and $6000 \mathrm{~m}$ above mean sea level (MSL), which is $\sim 1.6$ times larger than the global-average warming rate between 1970 and 2015. The warming rate between 5500 and $6000 \mathrm{~m}$ MSL was $\sim 1.5$ times greater than the rate at the $2000-2500 \mathrm{~m}$ MSL bin $\left(0.019^{\circ} \mathrm{C} \mathrm{a}^{-1}\right)$, which is similar to the majority of warming rates estimated worldwide over similar elevation gradients. Accelerated warming since 1979, measured by radiosondes, indicates a maximum rate at $400 \mathrm{hPa}(\sim 7010 \mathrm{~m} \mathrm{MSL})$. EDW in the St. Elias region therefore appears to be driven by recent warming of the free troposphere. MODIS satellite data show no evidence for an enhanced snow albedo feedback above $2500 \mathrm{~m}$ MSL, and declining trends in sulfate aerosols deposited in high-elevation ice cores suggest a modest increase in radiative forcing at these elevations. In contrast, increasing trends in water vapor mixing ratio at the $500-\mathrm{hPa}$ level measured by radiosonde suggest that a longwave radiation vapor feedback is contributing to EDW.
\end{abstract}

\section{Introduction}

The climate of high-elevation midlatitude mountains appears to be warming faster than the global average (Pepin et al. 2015). Similarly, high Arctic latitudes $\left(>60^{\circ} \mathrm{N}\right)$ are also warming faster than the global average, a phenomenon referred to as Arctic amplification (AA; Serreze et al. 2009). In contrast, elevation-dependent warming (EDW) describes warming rates that generally

Corresponding author: Scott N. Williamson, scott.williamson@ ualberta.ca increase with elevation, and can also include maximum warming rates found below mountain summits. Both EDW and Arctic amplification describe the increase of the temporal rate of change of near-surface air temperatures, although not necessarily as a monotonic function of elevation or latitude. Little is known about the extent or magnitude of EDW at high northern latitudes, but this information would greatly enhance our understanding of the functioning of Earth's rapidly evolving climate system. EDW appears in both modeling results (Giorgi et al. 1997; Chen et al. 2003) and observational studies (Bradley et al. 2004; Rangwala 2013; 
Pepin and Lundquist 2008), and most global climate model (GCM) simulations over mountain regions exhibit EDW, even though models contain a degree of uncertainty related to coarse spatial resolutions that fail to properly encapsulate regional climate (e.g., Salathé et al. 2008). Modeled warming in mountains has been observed at intermediate elevations, or as continuous warming to mountain peaks (e.g., Fyfe and Flato 1999; Bradley et al. 2004; Liu et al. 2009; Yan et al. 2016; Rangwala et al. 2016; Palazzi et al. 2018).

There has been considerable debate about the geographical ubiquity of EDW in observational studies (Pepin et al. 2015). Observations of EDW have been conducted primarily in midlatitude mountain ranges such as the European Alps, the Tibetan Plateau, the Andes, and parts of the North American Cordillera (e.g., Liu et al. 2009; Vuille et al. 2015). Wang et al. (2014) used paired low-elevation $[<500 \mathrm{~m}$ above mean sea level (MSL)] and high-elevation ( $>500 \mathrm{~m}$ MSL) temperature trend analysis for the North Tibetan Plateau, East Loess Plateau, southeast Rockies, and European Alps to show that the warming was 1.24 times faster at high elevations compared with low elevations for the 1961-2010 period. Furthermore, the warming rate for five Tibetan Plateau stations at $4500 \mathrm{~m}$, between 1976 and 2010, was 1.59 greater than the warming rates at $500 \mathrm{~m}$ for a global average of available data (Wang et al. 2016). Differences in EDW rates may arise due to both geographical differences between study areas and differences between datasets. For example, Oyler et al. (2015) found no statistically significant EDW in the western United States for the 1991-2012 period using homogenized data produced with the ParameterElevation Relationships on Independent Slopes Model (PRISM; Daly et al. 2008). You et al. (2010) found differences and inconsistencies between reanalysis datasets for the Tibetan Plateau, and observed no EDW above $2000 \mathrm{~m}$. These studies underscore the need for a robust validation scheme in order to accurately detect EDW in temperature reanalysis products, especially since EDW might not manifest itself as a globally uniform warming rate, or with a standard elevation for maximum warming rate.

Although modeling and observational studies provide evidence for EDW, the driving mechanism(s) remain uncertain. Previous studies have identified a number of potential causes for EDW, of which several are thought to be more influential at high latitude:

1) Snow albedo feedback (SAF) results from highalbedo snow being replaced with low-albedo bare ground as the air warms and the snow line rises. It has often been evoked as a causal mechanism, and possibly the main driver, for EDW (Giorgi et al. 1997; Fyfe and Flato 1999; Pepin and Lundquist 2008; Palazzi et al. 2017). Many studies of SAF report strong correlations between observations of warming maxima occurring near the freezing point of water and simulated patterns of temperature increase and snow-cover reductions, without strong evidence for causality. Recent observational evidence from the St. Elias region showed that SAF had a negligible effect on 2000-14 spring surface temperature trends in alpine tundra at $\sim 1500 \mathrm{~m}$ (Williamson et al. 2018).

2) Aerosols such as sulfate may cause or enhance EDW by disproportionally scattering solar radiation at lowertroposphere altitudes $(<\sim 3000 \mathrm{~m})$, where their optical depth is largest (Rangwala et al. 2010; Zeng et al. 2015). The aerosol mixing ratio typically decreases rapidly above $\sim 3000 \mathrm{~m}$ and should therefore have little radiative impact above this altitude (Ramanathan and Carmichael 2008).

3) The effect of clouds on surface air temperatures varies between day and night, between summer and winter, and with cloud type and altitude (Liu et al. 2009; Yan et al. 2016; Duan and Wu 2006). At high elevations the solar radiation flux is larger than at low elevations because clouds are optically thinner, therefore attenuating and reflecting less radiation. Multiple reflections between high-elevation high-albedo snow and high-altitude cloud layers can amplify solar radiation at high elevation, but the amount of amplification depends on solar angle and cloud amount. Longwave radiation emitted from the surface and atmosphere both tend to decrease with elevation because of decreasing temperature and water vapor content (e.g., Fliri 1971).

4) Water vapor feedback (WVF) describes how an increase in surface water vapor enhances downward longwave radiation. Global warming is predicted to be amplified by the WVF, which could be disproportionally large at high elevations (Hall and Manabe 1999; Held and Soden 2000; Rangwala 2013; Rangwala et al. 2009, 2010, 2016). Mountain regions close to an oceanic water vapor source, such as northwestern North America, could therefore be particularly susceptible to the WVF feedback (Kotlarski et al. 2012; Vuille et al. 2015; Walton et al. 2015). Energy absorption increases logarithmically when low water vapor mixing ratios increase, which predicts a strong positive longwave water vapor feedback mechanism in the upper troposphere (Held and Soden 2000). The warming effect of enhanced downward longwave radiation flux at high elevations has been detected in the Alps (Ruckstuhl et al. 2007) and on the Tibetan Plateau (Rangwala et al. 2009). 
5) Tropospheric warming has been identified as a possible source of EDW, with modeling studies suggesting that the climate will warm at the upper elevations in the troposphere as well as at Earth's surface (Bradley et al. 2004; Kotlarski et al. 2012; Rangwala et al. 2016; Rupp et al. 2017). The IPCC Fifth Assessment Report shows maximum warming in the free atmosphere at the $200-400-\mathrm{hPa}$ pressure levels in the range of representative concentration pathway (RCP) scenarios at low latitudes (Collins et al. 2013). This warming is caused by a decrease in the free-tropospheric lapse rates (Frierson 2006) which is largely driven by the moist adiabatic lapse rate decreasing with temperature (Kotlarski et al. 2012). Moreover, latent heat release from cloud condensation is most effective at the higher temperatures found at tropical latitudes and is expected to have little influence on EDW in the Arctic.

Detection of EDW at high northern latitudes is presently difficult, largely because there are few high-elevation meteorological stations north of $60^{\circ} \mathrm{N}$. Mean annual air temperatures over land surfaces north of $60^{\circ} \mathrm{N}$ are presently increasing at about twice the global-average rate (Serreze and Barry 2011), where the October 2017September 2018 annual anomaly (relative to 1981-2010) was $1.7^{\circ} \mathrm{C}$ (Osborne et al. 2018). The greatest warming has occurred in autumn and winter, while warming in the spring and summer has been comparatively limited. Unlike AA, EDW manifests itself in all seasons, likely due to the wide latitudinal distribution of high mountains (see Table 1 in Pepin et al. 2015). A recent evaluation of long-term climate records found no evidence for latitudinal or elevational temperature amplification within the Arctic over the 1961-2010 period (Wang et al. 2016). However, the highest meteorological station considered was situated $<1000 \mathrm{~m}$, which may be too low in elevation to detect an EDW signal, if it exists.

Two recent studies provide evidence for spring and summer EDW above $60^{\circ} \mathrm{N}$ in northwestern North America. Using air temperature reanalysis and satellite infrared data, Williamson et al. (2018) showed that in the St. Elias Mountains of southwest Yukon $\left(60^{\circ}-62^{\circ} \mathrm{N}\right.$, $137^{\circ}-142^{\circ} \mathrm{W}$ ), springtime (May) surface temperatures rose at rates from $0.14^{\circ} \mathrm{Ca}^{-1}$ at $1000 \mathrm{~m}$ to $0.19^{\circ} \mathrm{Ca}^{-1}$ at $5000 \mathrm{~m}$ during the years 2000-14. Farther west, analysis of melt layers (a proxy for summer warmth) in ice cores from Mount Hunter, Alaska $\left(63^{\circ} \mathrm{N}, 151^{\circ} \mathrm{W}\right)$, revealed an average warming trend at $3900 \mathrm{~m}$ of $0.0228^{\circ} \pm$ $0.0044^{\circ} \mathrm{Ca}^{-1}$ between 1950 and 2011 (Winski et al. 2018). Comparison to air temperature data from 15 lowelevation stations in Alaska and the Yukon suggests that summertime EDW is occurring on Mount Hunter.

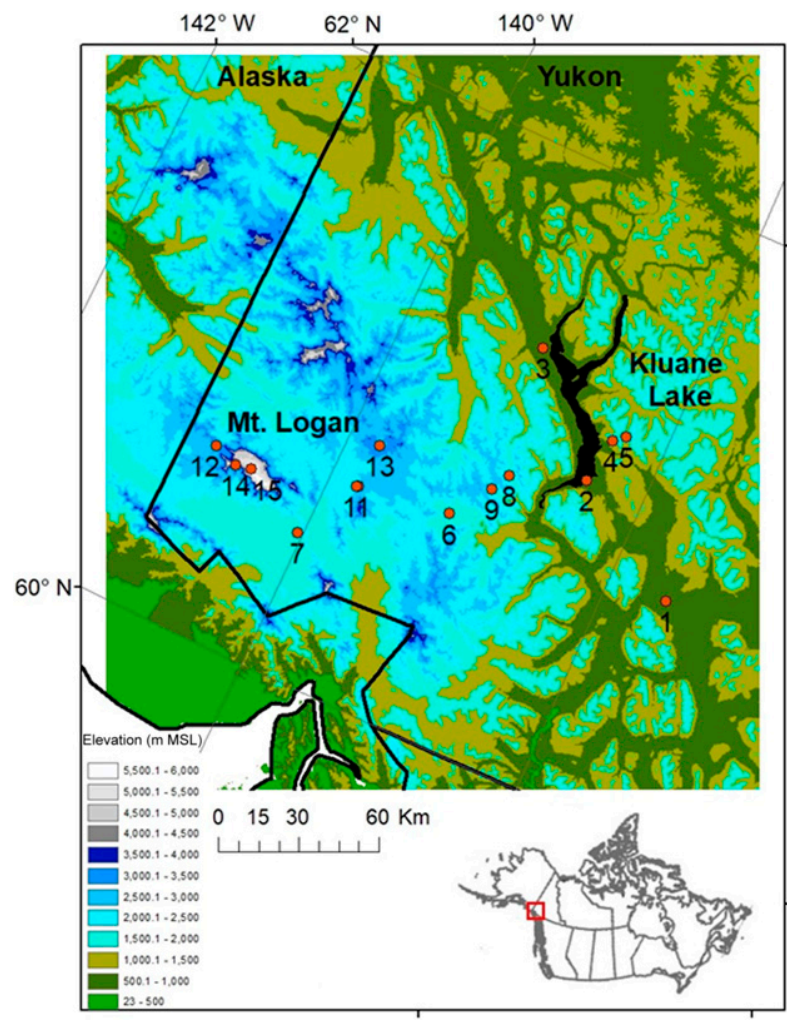

FIG. 1. Study area in southwest Yukon, focused on the St. Elias Mountains. The numbered red dots represent meteorological stations referred to in the text and Table 1 . Note that stations 10 and 11 are represented by the number 11 .

In this study, we use comprehensive meteorological station measurements to validate downscaled NARR air temperature data for the St. Elias Mountains, and quantify the magnitude of EDW in this high-latitude region. We also investigate the possible drivers of EDW by comparing reanalysis temperature trends and patterns with climate indices, vertical profiles of temperature and water vapor pressure from radiosondes, long-term climate information from high-elevation ice cores extracted from the St. Elias Icefield, and satellite measurements of high-elevation albedo.

\section{Study area}

The St. Elias Mountains and associated St. Elias Icefield stretch across parts of southeast Alaska, southwest Yukon and northwestern British Columbia (BC). The study area (Fig. 1) lies $\sim 6^{\circ}$ south of the Arctic Circle. The St. Elias Icefield is located near the terminus of the major storm track in the North Pacific (Blackmon 1976; Mesquita et al. 2010), and lies in the major mid- to uppertropospheric advection pathway for oceanic water vapor into northwestern Canada (Smirnov and Moore 1999). 
Prevailing low winter temperatures are caused by the orographic obstacle of the St. Elias and northern Coast Mountains (BC), which block the westerly flow of relatively mild Pacific air from the Gulf of Alaska (Wahl et al. 1987) and maintain anticyclonic conditions in the Yukon interior (Burn 1994). The blocking mechanism is further enhanced by an area of dominant high pressure in the eastern Yukon, while cold air drainage enhances winter inversions in valleys (Wahl et al. 1987). A recent paleoclimate record from subarctic Yukon shows that this region warmed rapidly in the industrial era, such that modern summer temperatures now exceed the Holocene thermal maximum by $1.7^{\circ} \pm 0.7^{\circ} \mathrm{C}$ (Porter et al. 2019).

This area was selected for a study of EDW for several reasons. 1) Meteorological station measurements of air temperature are available over a $\sim 5000-\mathrm{m}$ elevation gradient, thus providing an unparalleled dataset to validate, and test for homogeneity in, downscaled temperature reanalysis. 2) The St. Elias Mountains have $61.76 \mathrm{~km}^{2}$ above $5000 \mathrm{~m}$, most of which is the summit plateau of the Mount Logan massif. Summit plateaus of high mountains are typically more representative of the free troposphere than adjacent sites located in valley bottoms (Pepin and Seidel 2005), and this large area high in the atmospheric column maximizes the opportunity for interactions between the surface and free troposphere. 3) Ice core paleoclimate records from Mount Logan and Eclipse Icefield in the St. Elias Mountains provide a long-term context for observed recent climate trends in the region (Zdanowicz et al. 2014).

\section{Methods and data}

To determine the presence and strength of EDW in the study area, we used downscaled North American Regional Reanalysis (NARR) temperature data over the 1979-2016 period. Reanalysis data are used because of the scarcity of long-term ( $>10$ years) continuous highelevation meteorological observations is this region and in mountainous regions in general (Hik and Williamson 2019). The period $1979-2016$ spans 38 years, 8 years longer than the recommended minimum duration for robust climatic trend analysis (Bye et al. 2011). However, long-term reanalysis data can suffer from heterogeneity issues related to changes in data acquisition (e.g., sensors, density) over time. To validate the downscaled NARR data, we used data from an extensive network of meteorological stations situated throughout the southwest Yukon. Linear regression was then applied to the validated, downscaled NARR data, binned by elevation, to quantify EDW trends at different altitudes across the study area.
To investigate possible drivers of EDW, we examined trends in historical temperatures and atmospheric water vapor measured by radiosondes launched proximal to the study area, as well as trends in satellite observations of snow-cover albedo. Last, we applied multiple linear regression analysis to investigate possible teleconnections between temperature trends in our study area, the Pacific-North American pattern (PNA; Wallace and Gutzler 1981), and Pacific Ocean sea surface temperature (SST).

\section{a. Downscaling of North American Regional Reanalysis data}

The National Centers for Environmental Prediction (NCEP) produces NARR air temperature from surface, radiosonde, and satellite data assimilated in the Eta model (Mesinger et al. 2006). Atmospheric temperatures from NARR at 16 pressure levels between 1000 and $500 \mathrm{hPa}$ were downscaled using a modified method described in Jarosch et al. (2012). These pressure levels translate to elevations between sea level and $\sim 5430 \mathrm{~m}$. From the NARR archive, atmospheric temperature $T_{p}$ was extracted at 16 pressure levels $(500-1000 \mathrm{hPa})$ for each 3-h time step and all the $\sim 32 \mathrm{~km} \times 32 \mathrm{~km}$ cells in the study region. Pressure levels were then converted to elevation levels using geopotential heights $z_{p}$ from the archive. The thermal structure $\left(T_{p}, z_{p}\right)$ of the atmospheric column was then examined to identify layers in which the stratification was normal (i.e., temperature decreases with altitude) and layers in which it was inverted. At most, we allowed three layers within the atmospheric column; if more layers were detected, then the least prominent layers were merged with the most prominent ones. Within each layer (denoted $\alpha=1,2,3$ ), the lapse rate $\Gamma_{\alpha}$ was assumed to be constant. Thus, for points in a given layer $T \alpha(z)=T_{\alpha}^{0}+\Gamma_{\alpha} z$, values for $T_{\alpha}^{0}$ and $\Gamma_{\alpha}$ were found by least squares regression. From these results the location and temperature of the layer boundaries were calculated. If there was a single layer then we set $T_{2}^{0}=T_{3}^{0}=T_{1}^{0}$ and $\Gamma_{2}=\Gamma_{3}=\Gamma_{1}$ and for two layers $T_{3}^{0}=T_{2}^{0}$ and $\Gamma_{3}=\Gamma_{2}$. For spatially gridded data we wrote $\left[T_{\alpha}^{0}\right]_{i j}$ and $\left[\Gamma_{\alpha}\right]_{i j}$ where $\left(x_{i}, y_{j}\right)$ are Cartesian spatial coordinates in the NARR grid. We evaluated the temperature profile at a point $\left(x_{s}, y_{s}, z_{s}\right)$ within a cell bounded by $\left(x_{i}, y_{j}\right),\left(x_{i+1}, y_{j}\right),\left(x_{i}, y_{j+1}\right)$, and $\left(x_{i+1}, y_{j+1}\right)$ by evaluating $T\left(z_{s}\right)$ at each of the corner points of the cell and using bilinear interpolation (e.g., MATLAB interp2.m) to find $T\left(x_{s}, y_{s}, z_{s}\right)$. For any corner point that involves more than a single layer it was necessary to determine which layer encloses the site elevation $z_{s}$ and then used the appropriate $T_{\alpha}$ expression. NARR air temperatures were downscaled for the January 1979December 2016 period based on a digital elevation 
model that has a gridded resolution of $200 \mathrm{~m}$. The 3-h downscaled data were then aggregated to monthly and annual averages.

Jarosch et al. (2012) used 78 stations in southern British Columbia to validate their downscaling method in areas of high vertical relief, and found a mean bias of $0.5^{\circ} \mathrm{C}$ and a mean absolute error $\leq 2^{\circ} \mathrm{C}$ for monthly averages from 1990 to 2008. The 200-m downscaled NARR grid cells above $\sim 5400 \mathrm{~m}(<500 \mathrm{hPa})$ in our study are generated by extrapolation up to $6000 \mathrm{~m}$ MSL using the lapse rate calculated from the NARR data between 1000 and $500 \mathrm{hPa}$. The accuracy of the downscaled NARR data in the St. Elias region has been confirmed with MODIS land surface temperature measurements (Williamson et al. 2018, 2017). For the present study, the downscaled NARR air temperatures for 1979-2016 were aggregated into 500-m elevation bins starting at $1000 \mathrm{~m}$.

\section{b. Meteorological observations}

The downscaled NARR data were validated against the most comprehensive meteorological temperature dataset ever assembled for a high-elevation, high-latitude location, and includes data from elevations higher than those in the GHCNv3 database (highest elevation in the daily database is $5033 \mathrm{~m}$ ) of homogenized stations (Lawrimore et al. 2011) (Fig. 1; Table 1). The oldest temperature measurements date to the establishment of a monitoring station at Kluane Lake (Lhù'ààn Mân) in December 1946, which continued operation until the end of August 1983. This station (station 2b) collected minimum and maximum air temperatures, using analog thermometers housed in a wooden Stevenson screen. Meteorological measurements otherwise commenced in the 1960s with the establishment of Environment and Climate Change Canada (ECCC) stations in Haines Junction (station 1) and Burwash Landing (station 3). These long-term ECCC records contain data gaps of various lengths and comprise the amalgamation of different stations and sensors established in close proximity to one another. All ECCC data and station information were acquired through the Government of Canada's Historical Climate Archive (http://climate.weather.gc.ca/ historical_data/search_historic_data_e.html).

The remainder of the data was measured after 2000 using a variety of ad hoc automated (unmanned) stations established and operated by individual researchers (Table 1). All modern station data were collected as hourly averages of subhourly sampling intervals (e.g., $5 \mathrm{~min}$ ) except at ECCC stations where temperatures are sampled on the hour. Air temperatures were measured at, or near, 2-m height using professionally calibrated digital sensors housed in passively vented radiation shields.
Not all sensors at these stations were subject to regular recalibration, and data collected by some may not meet World Meteorological Organization (WMO) standards in this regard. Stations 12 to 15 , established above $2690 \mathrm{~m}$, only collected data for 1-2 years before they were relocated, damaged, or permanently buried by snow and lost. Air temperatures measured by each of the 15 stations were aggregated into monthly averages for each station. Any station where less than $90 \%$ of the hourly observations were recorded for a given month had that month excluded from the analysis. This occurred for $1 / 3$ of the datasets, where the missing data typically accounted for $<3 \%$ of records, but up to $22 \%$ of records at King Col on Mount Logan (station 14 in Table 1). The monthly averages were then compared to the downscaled NARR air temperature for the 200-m grid cell containing each station.

\section{c. Radiosonde observations}

Starting in 1958, radiosondes have been launched twice daily at 2400 and 1200 UTC [1600 and 0400 Pacific standard time (PST)] from the Yakutat airport (YAK), Alaska $\left(59.5120^{\circ} \mathrm{N}, 139.6710^{\circ} \mathrm{W} ; 9 \mathrm{~m}\right)$ and the Whitehorse airport (YXY), Yukon $\left(60.73306^{\circ} \mathrm{N}\right.$, $\left.135.0978^{\circ} \mathrm{W} ; 707 \mathrm{~m}\right)$. Yakutat lies on the coast of the Gulf of Alaska, $\sim 10 \mathrm{~km}$ south and $\sim 50 \mathrm{~km}$ west of the study area, whereas Whitehorse is located $\sim 90 \mathrm{~km}$ to the east and $\sim 10 \mathrm{~km}$ to the north in the Yukon Intermontane Belt. Whitehorse radiosonde data are missing from October 1971 to December 1972, inclusive. Radiosondes record air temperature and vapor pressure at discrete pressure levels between the surface and upper stratosphere. For this study, data from the 300-, 400-, 500-, and 700-hPa pressure levels were analyzed, which correspond to altitudes of $\sim 8940, \sim 7010, \sim 5430$, and $\sim 2920 \mathrm{~m}$, respectively. The radiosondes launched at Yakutat typically drift westward over the southern part of the St. Elias Mountains.

The high latitude of the study area dictates large seasonal differences in the time of sunrise and sunset. For this reason, only radiosonde data recorded at 1200 UTC (0400 PST) were used. These soundings give a more consistent and uniform sample of minimum diurnal temperatures than 0000 UTC (1600 PST) soundings for daily maximum temperatures. Radiosonde measurements of air temperature can be biased by solar radiative warming at high altitudes; however, below the 500-hPa pressure level the corrections are small (Elliott et al. 2002). The use of nighttime radiosonde data helps to mitigate spurious data, especially at the $400-\mathrm{hPa}$ level and above. Heterogeneities in the water vapor records at the 400-hPa level were introduced by instrument changes made during the 1980s in the U.S. National Weather 


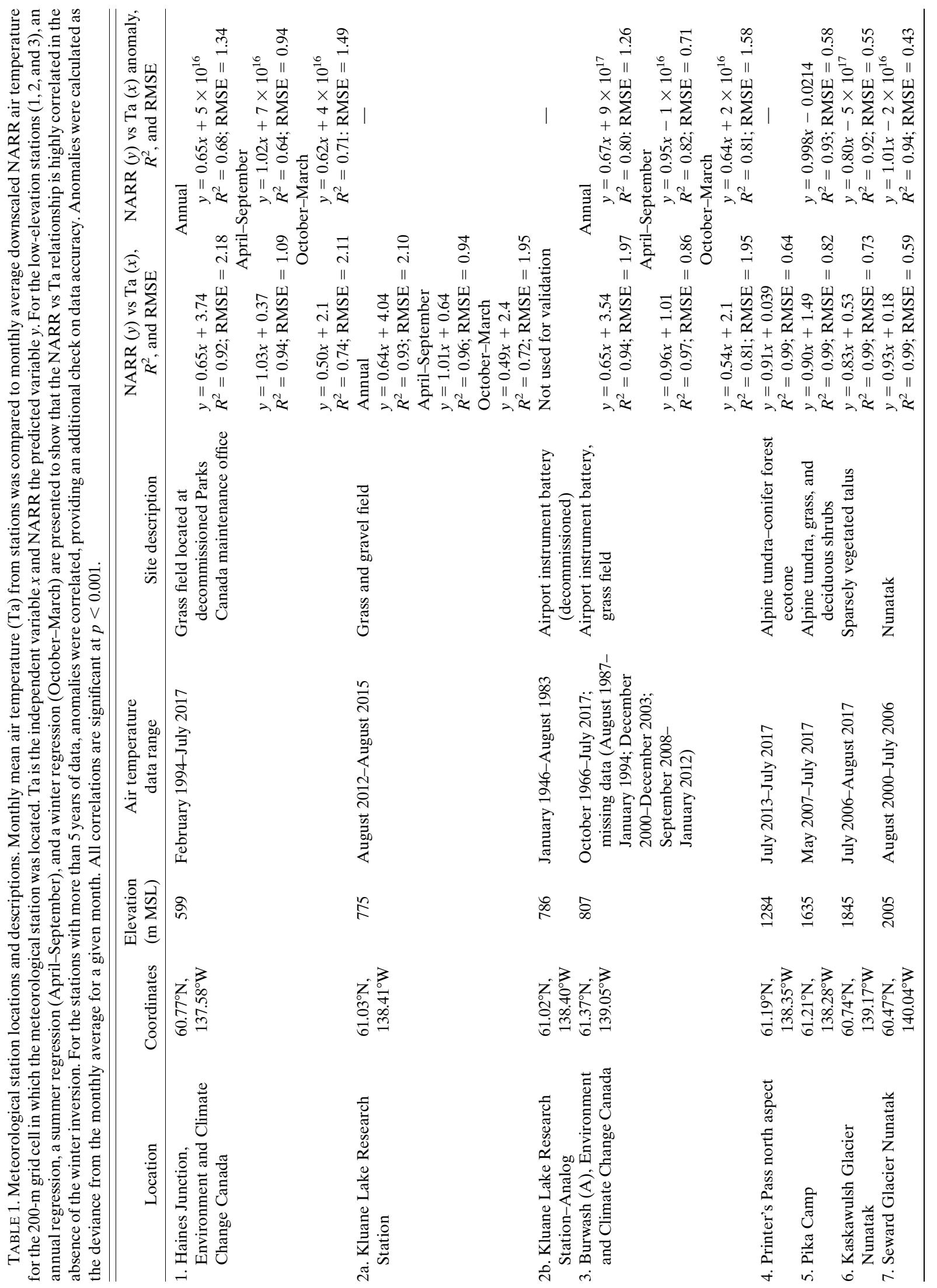




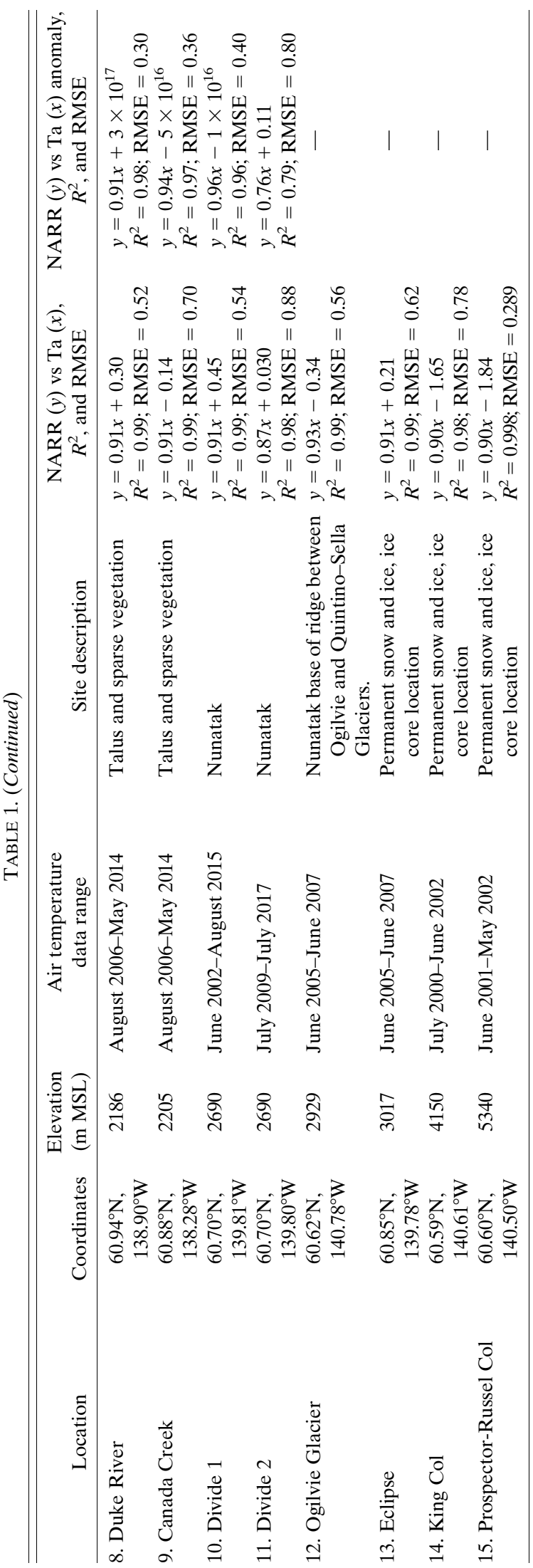

Service radiosondes (e.g., Elliott et al. 2002), which preclude reliable trend analysis of these data. However, humidity values at altitudes below the 500 -hPa pressure level have been shown to be consistent between instruments (Elliott et al. 2002). All radiosonde data used here were downloaded from the National Oceanic and Atmospheric Administration (https://www1.ncdc.noaa.gov/ pub/data/igra/).

\section{d. PNA and Niño-3.4 sea surface temperature}

We compared temperature from the downscaled NARR to the PNA index and to the Niño-3.4 east central tropical Pacific SST dataset $\left(5^{\circ} \mathrm{N}-5^{\circ} \mathrm{S}, 170^{\circ}-120^{\circ} \mathrm{W}\right)$ at the annual time scale. The PNA describes a large-scale pattern of extratropical, low-frequency atmospheric variability that oscillates between two opposite phases. In its positive phase, western Canada experiences air temperatures that are above average. Temperature and precipitation anomalies during the positive phases of the PNA phase are typically opposite of the negative phase.

Monthly PNA indices were obtained from http:// www.cpc.ncep.noaa.gov/products/precip/CWlink/pna/ pna_index.html, and monthly Niño-3.4 SST values were obtained from https://www.esrl.noaa.gov/psd/data/ correlation/nina34.data.

\section{e. MODIS snow albedo}

The snow albedo data used in this study (MOD10A1) were acquired by the MODIS sensor on the Terra satellite for cloud-free daytime conditions (Hall et al. 2002), and processed by the National Snow and Ice Data Center (Stroeve et al. 2006). MOD10A1 records broadband albedo using a directional-hemispherical reflectance as under direct illumination (Klein and Stroeve 2002). The average albedo over the snowmelt season (1 April30 September) was calculated from daily $500 \mathrm{~m} \times 500 \mathrm{~m}$ albedo grid cells with valid albedo values $(0-0.99)$ for the years 2000-16. These averages were then aggregated in 500-m elevation bins commencing at $1000 \mathrm{~m}$, to match the elevation bins of the downscaled NARR temperature data. MODIS snow albedo (MOD10A1) values are on average within $<5 \%$ of albedo field measurements recorded at elevations up to $2600 \mathrm{~m}$ in the St. Elias Icefield (Williamson et al. 2016).

\section{f. Statistical analysis}

Linear trends in the annually averaged time series of downscaled NARR temperatures, radiosonde temperatures, and water vapor pressure were calculated by ordinary least squares (OLS) linear regression, as was done in related studies (e.g., Pepin and Lundquist 2008; Liu et al. 2009; Qin et al. 2009; Rangwala et al. 2010; Palazzi et al. 2017). Trends were calculated for discrete 
500-m elevation bins, and from these results, the linear rate of temperature change with respect to elevation was determined. All trends were evaluated for statistical significance using a $t$ test (e.g., Palazzi et al. 2018). Time series often suffer from heteroscedasticity and autocorrelation, which can compromise the interpretation of OLS regression. We tested for heteroscedasticity using the Breusch-Pagan test and corrected for the effects of heteroscedasticity and autocorrelation, where necessary, using robust standard errors. Multiple linear regression (e.g., Palazzi et al. 2017) was used to explore the relationship between the PNA index, tropical Pacific SST, and air temperature trends in the St. Elias Mountains. For all statistical tests, results with $p<0.05$ were considered significant, although results with $p<$ 0.1 are also reported. All statistical analyses were carried out using the $\mathrm{R}$ software package (version 3.4.3).

\section{Results}

\section{a. Validation of downscaled NARR data against meteorological data}

The downscaled NARR data correlate exceedingly well $\left(0.92 \leq R^{2} \leq 0.99 ; 0.29^{\circ} \leq \mathrm{RMSE} \leq 2.18^{\circ} \mathrm{C}\right.$; $p<0.001$ ) with air temperature measurements from 15 meteorological stations spanning elevations from 599 to $5340 \mathrm{~m}$ (Table 1) using monthly averages. The strongest correlations $\left(R^{2} \geq 0.98\right)$ are found for elevations $>1200 \mathrm{~m}$. In valley bottoms, where stations $1,2 \mathrm{a}$, and 3 were located, the winter months' (October-March) downscaled air temperatures were $\sim 10^{\circ} \mathrm{C}$ warmer than the station temperatures and the correlation coefficient ranged from $R^{2}=0.72$ to 0.81 . This is likely due to inversions that are not detected at the native $32-\mathrm{km}$ gridcell resolution of the original NARR data, and are uncorrected for in the downscaled product. Furthermore, synoptic conditions could enhance or prevent inversions, which would influence the EDW profile. In view of these limitations, we conduct our trend analysis at elevations above $2000 \mathrm{~m}$.

The downscaled NARR air temperatures for the summer months at all elevations, and for the winter months above $1200 \mathrm{~m}$, display $R^{2}$ values $>0.94$ and RMSE $<1.1^{\circ} \mathrm{C}$ when compared to meteorological station air temperature; the majority of $R^{2}$ values exceed 0.98 and the majority of RMSE values are less than $0.9^{\circ} \mathrm{C}$. These high correlations indicate that the spatial distribution of downscaled NARR temperature data is a good estimate of the temperature fields found in the study area.

As a further check on the consistency and accuracy of the downscaled NARR temperature data, we correlated monthly anomalies for NARR and meteorological station air temperatures (Table 2). Anomalies are the
TABLE 2. Annual rate of change and standard error (SE) for 500$\mathrm{m}$ elevation bins [above mean sea level (MSL)] for downscaled NARR temperature, 1979-2016. Italicized values are significant at $p<0.10$; boldface values are significant at $p<0.05$.

\begin{tabular}{cc}
\hline \hline Elevation bin $(\mathrm{m} \mathrm{MSL})$ & Trend $\pm \mathrm{SE}\left({ }^{\circ} \mathrm{Ca}^{-1}\right)$ \\
\hline $5500-6000$ & $\mathbf{0 . 0 2 8} \pm 0.013$ \\
$5000-5500$ & $\mathbf{0 . 0 2 7} \pm 0.013$ \\
$4500-5000$ & $\mathbf{0 . 0 2 6} \pm 0.013$ \\
$4000-4500$ & $\mathbf{0 . 0 2 5} \pm 0.012$ \\
$3500-4000$ & $\mathbf{0 . 0 2 4} \pm 0.012$ \\
$3000-3500$ & $\mathbf{0 . 0 2 2} \pm 0.012$ \\
$2500-3000$ & $0.021 \pm 0.012$ \\
$2000-2500$ & $0.019 \pm 0.012$ \\
\hline
\end{tabular}

deviation from the mean value of a reference period, typically set to be 30 years in duration. Here the data records are too short to adequately determine a reference period. As a way to reduce the influence of the annual cycle on the correlation between air temperature and NARR, we determined the difference between monthly averages and that particular month's measurements. These pseudoanomalies were calculated for data records of more than five years. When these anomalies for air temperature and the corresponding NARR grid were regressed, the summer (April-September) anomalies below $1500 \mathrm{~m}$ fell very close to the $1: 1$ line and above $1500 \mathrm{~m}$ the anomalies were highly correlated $\left(R^{2}\right.$ values ranged from 0.79 to 0.98 ).

The downscaled NARR air temperature data from the 5000-5500- and 2500-3000-m bins are correlated with the 1200 UTC radiosonde temperatures from Yakutat and Whitehorse at the 500- and 700-hPa pressure levels (Fig. 2). The NARR and radiosonde temperature correlations for Yakutat are $R^{2}=0.93$ at $500 \mathrm{hPa}$ and $R^{2}=0.88$ at $700 \mathrm{hPa}$. At Whitehorse the correlations are $R^{2}=0.81$ at $500 \mathrm{hPa}$ and $R^{2}=0.73$ at $700 \mathrm{hPa}$. All four correlations are statistically significant at the $p<0.01$ level.

\section{b. Elevation-dependent temperature patterns from downscaled NARR data}

Linear trends of monthly mean temperatures were calculated for each downscaled NARR grid cell between 1979 and 2016, and these were then averaged to get the trends in mean annual temperatures. The Shapiro-Wilk test applied to the annual time series shows that the data were normally distributed, indicating that the linear regression was appropriate for trend analysis. The Breusch-Pagan test revealed heteroscedasticity in the annual time series below $4500 \mathrm{~m}$, but not above. Trend analysis with robust standard errors produced only slightly lower $p$ values than ordinary linear regression. From this we conclude that the ordinary linear regressions 


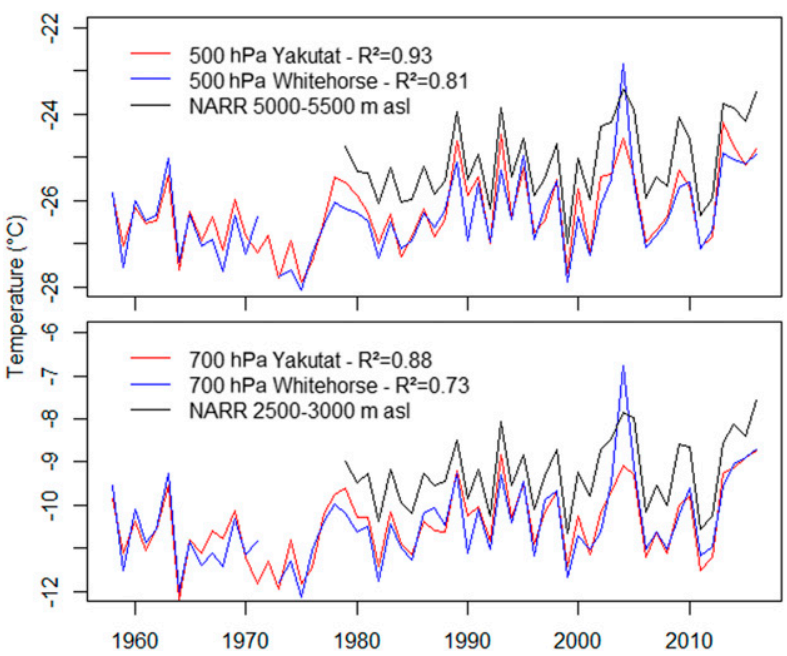

FIG. 2. Time series of downscaled NARR mean annual air temperatures (black lines) over the study region from 1979 to 2016 for the 500-m bins at (top) 5000-5500 and (bottom) $2500-3000 \mathrm{~m}$ MSL. The annual air temperature time series from the 1200 UTC radiosonde at (top) 500 and (bottom) $700 \mathrm{hPa}$, launched at Yakutat (red lines) and Whitehorse (blue lines), are included. Correlation coefficients between the radiosonde air temperature and the corresponding NARR elevation bin temperature follow the pressure level and radiosonde launch site.

are appropriate for determining linear slope and the effects of heteroscedasticity and autocorrelation in the downscaled NARR time series regression are minimal.

Linear trends in mean annual surface temperatures between 1979 and 2016 are mapped in Fig. 3, and listed by $500-\mathrm{m}$ elevation bins in Table 2 . The temperatures display positive trends in all elevation bins, which increase monotonically from $0.019^{\circ} \mathrm{Ca}^{-1}$ between 2000 and $2500 \mathrm{~m}$ to $0.028^{\circ} \mathrm{Ca}^{-1}$ at the $500-\mathrm{m}$ elevation bin $>5500 \mathrm{~m}$. Trends between 2000 and $3000 \mathrm{~m}$ are significant at the $90 \%$ confidence level $(p<0.10)$, and those between 3000 and $6000 \mathrm{~m}$ are significant at the $95 \%$ confidence level $(p<0.05)$. The highest warming rates are observed on isolated peaks above $5000 \mathrm{~m}$, such as at Mount Logan.

\section{c. Tropospheric temperature and vapor pressure trends from radiosonde data}

The time series of radiosonde-based mean annual air temperatures and water vapor pressures for different pressure levels above Yakutat and Whitehorse are displayed in Figs. 4 and 5 . Analysis of these data reveals positive and significant temperature trends at most pressure levels above the two stations over the entire period (1958-2016) and steeper warming rates during the more recent period (1979-2016) covered by the downscaled NARR temperature data (top half of

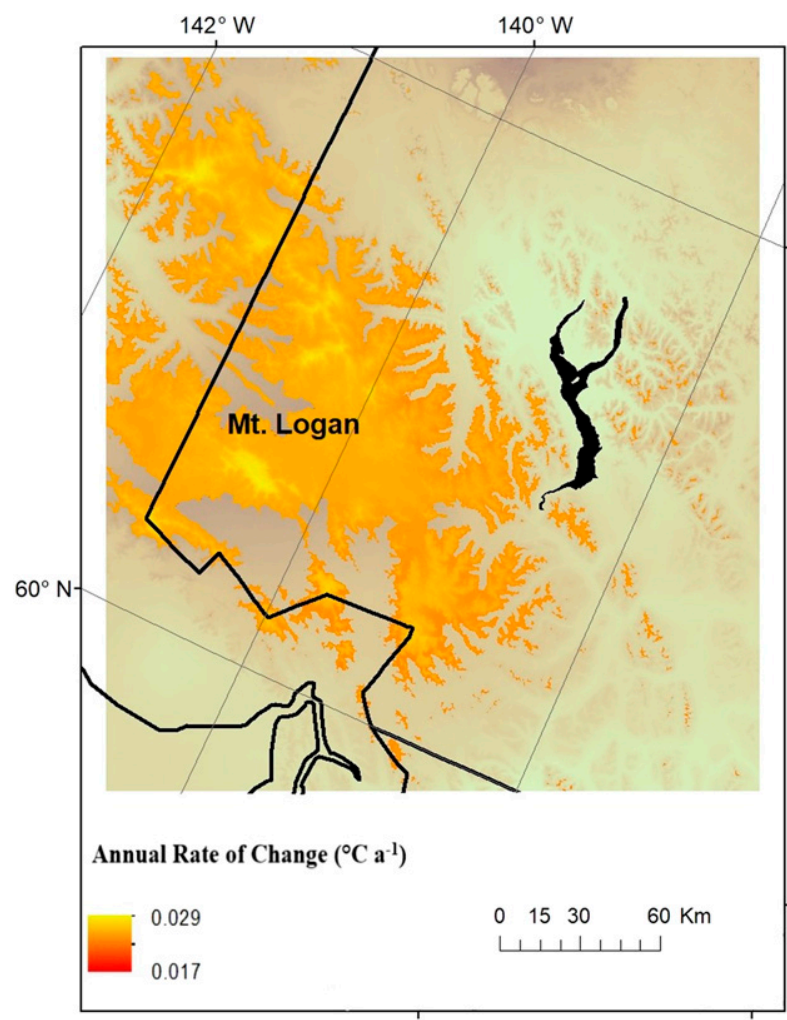

FIG. 3. The spatial distribution of linear surface warming rates $\left({ }^{\circ} \mathrm{Ca}^{-1}\right)$ between 1979 and 2016 derived from the downscaled NARR air temperature data. Warming rates above $3000 \mathrm{~m}$ MSL are statistically significant at the $p<0.05$ level and are displayed in the red-to-yellow color palette.

Table 3; $p<0.10$ to $p<0.05$ ). The maximum warming rates for the 1979-2016 period occur at the 400-hPa level $(\sim 7010 \mathrm{~m})$ as measured by radiosondes launched from Whitehorse and Yakutat. Unlike the EDW trend seen in the downscaled NARR surface temperatures, radiosonde air temperatures up to $\sim 7010 \mathrm{~m}$ appear to have increased uniformly (Fig. 6). Comparing the 1958-2016 and 1979-2016 trends indicates a higher rate of warming during the more recent period.

Owing to sensor changes in the radiosondes, heterogeneities in the 400-hPa water vapor pressure appear in the Yakutat record in 1994 and in the Whitehorse record in 1984. Trends in these data over the period 1958-2016 are consequently subject to enhanced uncertainties, so we report post-1994 and post-1984 trends separately (bottom half of Table 3). The atmospheric water vapor pressure increased significantly in the Yakutat-launched radiosonde data $(500-$ and $700-\mathrm{hPa}$ levels; $p<0.05)$ and in those launched from Whitehorse (700-hPa level; $p<0.05$ ) between 1958 and 2016. To put these increases in context, the average 1958-2016 water vapor pressure at $500 \mathrm{hPa}$ was $398.6 \mathrm{~Pa}$ and at $700 \mathrm{hPa}$ was $1969.9 \mathrm{~Pa}$. 


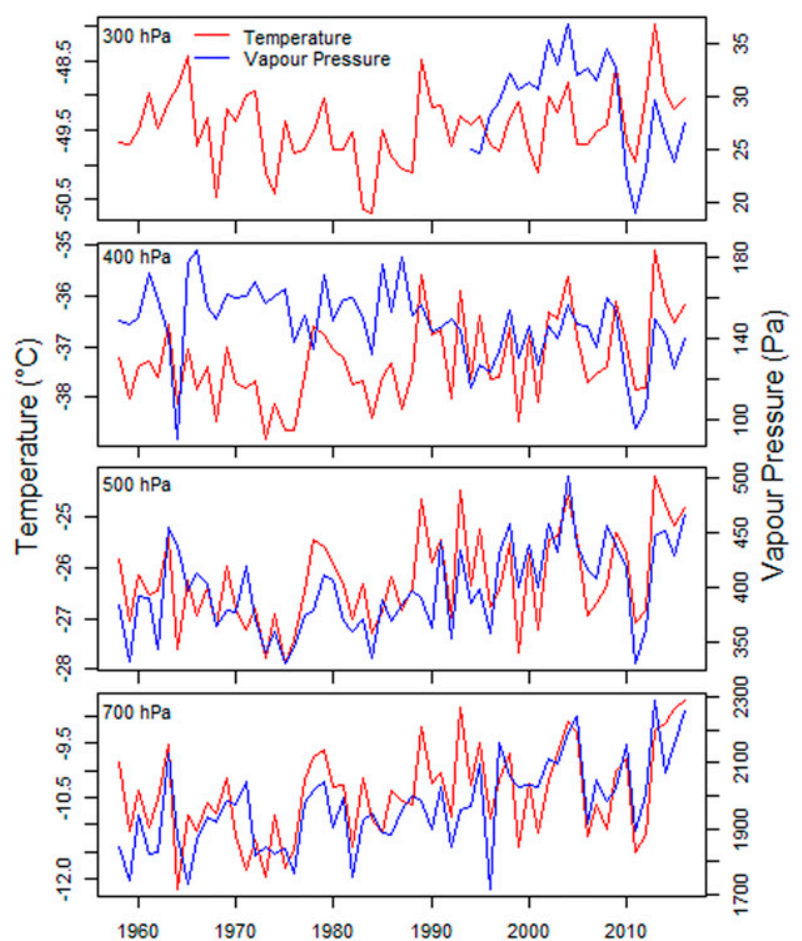

FIG. 4. Yakutat, Alaska, 1200 UTC radiosonde measurements of annually averaged air temperatures (red lines) and water vapor pressures (blue lines) at the (top to bottom) 300-, 400-, 500-, and 700-hPa pressure levels between 1958 and 2016. Instrument upgrades provide an increase in sensitivity to water vapor at $300 \mathrm{hPa}$ that commence in 1994. Homogeneity issues in the 400-hPa water vapor pressure time series are visible before and after 1994, making trend analysis on the full length of the time series unrealistic.

In more recent decades (post-1994 or post-1984), water vapor pressure shows statistically significant increases at the 400- and 500-hPa levels from Whitehorse $(p<0.05)$, but not from Yakutat.

\section{d. Elevation-dependent MODIS snow albedo patterns}

Analysis of the aggregated MODIS snow albedo data for the melt season (April-September) revealed weak positive trends over the study region between 2000 and 2016, but no trends were statistically significant $(p>0.05)$. The mean albedo was $0.63 \pm 0.03(1 \sigma)$ between 3000 and $3500 \mathrm{~m}$, and increased monotonically with elevation to $0.73 \pm 0.01$ between 5500 and $6000 \mathrm{~m}$.

\section{Discussion}

Our analysis of downscaled NARR temperature data shows that annual surface air temperatures in the St. Elias Mountains have been increasing since 1979 at all elevations from 2000 to $6000 \mathrm{~m}$. We find evidence of a statistically significant $(p<0.05)$ EDW pattern above

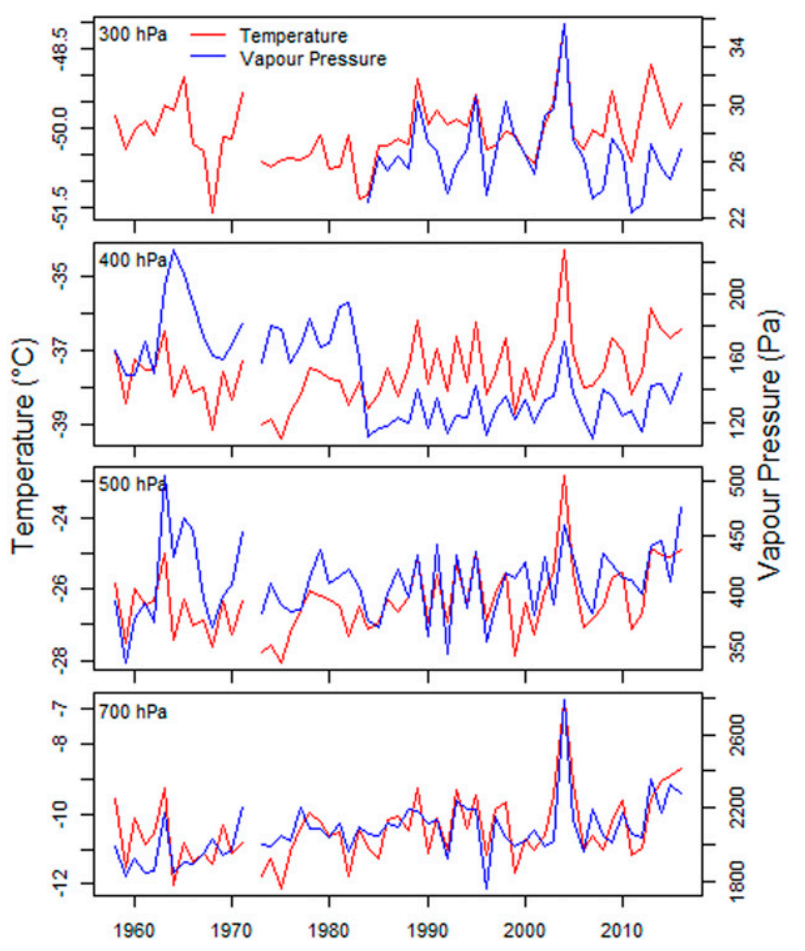

FIG. 5. Whitehorse, Yukon, 1200 UTC radiosonde measurements of annually averaged air temperatures and water vapor pressures at the (top to bottom) 300-, 400-, 500-, and 700-hPa pressure levels between 1958 and 2016. Instrument upgrades provide an increase in sensitivity to water vapor at $300 \mathrm{hPa}$ that commence in 1984 . Homogeneity issues in the 400-hPa water vapor pressure time series are clearly visible before and after 1984, making trend analysis on the full length of the time series unrealistic.

$3000 \mathrm{~m}$. The greatest warming rates occur above $5500 \mathrm{~m}$. The mean annual warming rate for the $5500-6000 \mathrm{~m}$ MSL bin is $0.028^{\circ} \mathrm{Ca}^{-1}$, compared to $0.019^{\circ} \mathrm{Ca}^{-1}$ at 2000-2500 m, which translates to an EDW amplification factor of 1.5 between these elevations. The greatest surface warming rate of $0.028^{\circ} \mathrm{Ca}^{-1}$, between 5500 and $6000 \mathrm{~m}$, is approximately half that of the fastest warming region of the Tibetan Plateau at $\sim 4500 \mathrm{~m}$, which warmed at $0.038^{\circ} \mathrm{Ca}^{-1}$ between 1961 and 2010 (Wang et al. 2016). The highest elevation bin analyzed here $(5500-6000 \mathrm{~m})$ is above the highest input pressure level (i.e., $500 \mathrm{hPa}$ ) but the close agreement to the bin below, which does include radiosonde measurements, indicates that the temperature trends are very likely correct. Summit plateaus of high mountains are typically more representative of the free troposphere than adjacent sites located in valley bottoms (Pepin and Seidel 2005). If this holds true for high mountains in the St. Elias, then a part of the EDW trend found in the NARR surface air temperature appears related to the land surface below $3000 \mathrm{~m}$ not warming as fast as the atmosphere. 
TABLE 3. Annual rate of change and standard error for 1200 UTC radiosonde measurements of air temperature and water vapor for Yakutat, Alaska, and Whitehorse, Yukon. Italicized values are significant at $p<0.10$, and boldface values are significant at $p<0.05$.

\begin{tabular}{|c|c|c|c|c|}
\hline \multirow[b]{2}{*}{ Elevation (pressure) } & \multicolumn{2}{|c|}{ Yakutat } & \multicolumn{2}{|c|}{ Whitehorse } \\
\hline & Period & Trend $\pm \mathrm{SE}\left({ }^{\circ} \mathrm{Ca}^{-1}\right)$ & Period & Trend $\pm \operatorname{SE}\left({ }^{\circ} \mathrm{Ca}^{-1}\right)$ \\
\hline \multicolumn{5}{|l|}{ Air temperature } \\
\hline \multirow[t]{3}{*}{$\sim 8940 \mathrm{~m}(300 \mathrm{hPa})$} & 1958-2016 & $0.005 \pm 0.004$ & 1958-2016 & $0.009 \pm 0.005$ \\
\hline & 1979-2016 & $\mathbf{0 . 0 2 1} \pm 0.008$ & 1979-2016 & $\mathbf{0 . 0 2 4} \pm 0.009$ \\
\hline & 1994-2016 & $0.027 \pm 0.014$ & 1984-2016 & $0.019 \pm 0.011$ \\
\hline \multirow[t]{3}{*}{$\sim 7010 \mathrm{~m}(400 \mathrm{hPa})$} & 1958-2016 & $\mathbf{0 . 0 2 0} \pm 0.006$ & 1958-2016 & $\mathbf{0 . 0 2 0} \pm 0.006$ \\
\hline & 1979-2016 & $\mathbf{0 . 0 2 7} \pm 0.012$ & 1979-2016 & $\mathbf{0 . 0 3 2} \pm 0.013$ \\
\hline & 1994-2016 & $0.043 \pm 0.026$ & 1984-2016 & $0.032 \pm 0.016$ \\
\hline \multirow[t]{3}{*}{$\sim 5430 \mathrm{~m}(500 \mathrm{hPa})$} & 1958-2016 & $\mathbf{0 . 0 2 1} \pm 0.006$ & 1958-2016 & $\mathbf{0 . 0 2 1} \pm 0.007$ \\
\hline & 1979-2016 & $0.024 \pm 0.013$ & 1979-2016 & $\mathbf{0 . 0 2 9} \pm 0.014$ \\
\hline & 1994-2016 & $0.048 \pm 0.029$ & 1984-2016 & $0.031 \pm 0.018$ \\
\hline \multirow[t]{3}{*}{$\sim 2920 \mathrm{~m}(700 \mathrm{hPa})$} & 1958-2016 & $\mathbf{0 . 0 1 9} \pm 0.006$ & 1958-2016 & $\mathbf{0 . 0 2 2} \pm 0.007$ \\
\hline & 1979-2016 & $0.017 \pm 0.012$ & 1979-2016 & $\mathbf{0 . 0 2 9} \pm 0.014$ \\
\hline & 1994-2016 & $0.035 \pm 0.027$ & 1984-2016 & $0.029 \pm 0.018$ \\
\hline \multicolumn{5}{|l|}{ Water vapor } \\
\hline$\sim 8940 \mathrm{~m}(300 \mathrm{hPa})$ & 1994-2016 & $-0.002 \pm 0.001$ & 1984-2016 & No trend \\
\hline$\sim 7010 \mathrm{~m}(400 \mathrm{hPa})$ & 1994-2016 & $-0.001 \pm 0.005$ & 1984-2016 & $\mathbf{0 . 0 0 6} \pm 0.002$ \\
\hline \multirow[t]{3}{*}{$\sim 5430 \mathrm{~m}(500 \mathrm{hPa})$} & 1958-2016 & $\mathbf{0 . 0 1 0} \pm 0.003$ & 1958-2016 & $0.003 \pm 0.003$ \\
\hline & 1979-2016 & $\mathbf{0 . 0 1 7} \pm 0.005$ & 1979-2016 & $0.008 \pm 0.004$ \\
\hline & 1994-2016 & $0.010 \pm 0.013$ & 1984-2016 & $\mathbf{0 . 0 1 4} \pm 0.005$ \\
\hline \multirow[t]{3}{*}{$\sim 2920 \mathrm{~m}(700 \mathrm{hPa})$} & 1958-2016 & $\mathbf{0 . 0 4 7} \pm 0.008$ & 1958-2016 & $\mathbf{0 . 0 4 3} \pm 0.001$ \\
\hline & 1979-2016 & $0.065 \pm 0.016$ & 1979-2016 & $0.035 \pm 0.023$ \\
\hline & 1994-2016 & $0.066 \pm 0.039$ & 1984-2016 & $0.035 \pm 0.031$ \\
\hline
\end{tabular}

Our estimated maximum warming rate of $0.028^{\circ} \mathrm{Ca}^{-1}$ for the upper $500-\mathrm{m}$ elevation band of the St. Elias Mountains is 1.6 times larger than the global-mean warming rate of $0.017^{\circ} \mathrm{Ca}^{-1}$ (NOAA 2016) over the 1970-2015 period. Temporal warming trends appear to be accelerating globally. At high elevations in midlatitudes Wang et al. (2016) found evidence that the temporal warming trends have steepened in the recent decades. In the subarctic, Winski et al. (2018) found evidence for temporal warming trend acceleration over the last several decades, and more generally in the Arctic air temperature strongly departed from the global average after 2001 (Osborne et al. 2018). The downscaled NARR trends are not long enough for a robust analysis of temperature acceleration. However, the radiosonde air temperatures trends show clear evidence of accelerated warming since 1979 (Fig. 6).

Ice cores from Mount Logan's Prospector-Russell Col (PR Col; $5340 \mathrm{~m})$, King Col $(4135 \mathrm{~m})$, and Eclipse Icefield $(3017 \mathrm{~m})$ in the St. Elias Mountains, and ice cores from Mount Hunter (3900 m) in Denali National Park provide a long-term ( $>1000$ years) historical context for the evolution of high-elevation climate in the region. In southeast Alaska, Winski et al. (2018) estimated a summer (July and August) warming rate of $0.0228^{\circ} \pm$ $0.0044^{\circ} \mathrm{Ca}^{-1}$ between 1950 and 2011 from the Mount Hunter ice core. This value is very similar to the annual NARR trend estimate for the 1979-2016 period in the
St. Elias Mountains for the 3500-4000-m elevation bin. Our estimate of the EDW amplification factor in the St. Elias Mountains (1.5 from 2000-2500 m to 5500-6000 m) is also close to those calculated by Winski et al. (2018) at Mount Hunter over a comparable range of elevations ( $\sim 1.5$ to 2.4 from $\sim 400$ to $3900 \mathrm{~m}$ ). The rate of warming at Mount Hunter was dependent on how the air temperatures from the 15 stations were aggregated: using a mean of daily mean temperatures produced a warming rate of $0.0153^{\circ} \pm 0.0123^{\circ} \mathrm{Ca}^{-1}$, while using a mean of daily maximum temperatures produced $0.0094^{\circ} \pm 0.0142^{\circ} \mathrm{Ca}^{-1}$. The corresponding EDW amplification factor (between $3900 \mathrm{~m}$ and $\sim 400 \mathrm{~m}$ ) in summer months is between 1.5 and 2.4 for 1950-2011 and is similar to the majority of EDW rates measured in the $30^{\circ}-40^{\circ} \mathrm{N}$ latitude band.

Atmospheric teleconnections from the tropical and North Pacific Ocean (Fisher et al. 2008, 2004; Osterberg et al. 2014; Winski et al. 2017) influence summer temperature trends in northwestern North America. Evidence for these teleconnections can be found in the ice cores extracted from the St. Elias region. Sea salt records in the Denali and Mount Logan PR cores indicate that North Pacific winter warming is determined by the strength of the Aleutian low, which has intensified over the twentieth century (Osterberg et al. 2017). Melt-layer variations in the Mt. Hunter ice core record are also significantly $(p<0.05)$ correlated with central tropical Pacific sea surface temperatures via a pattern similar to that of a 


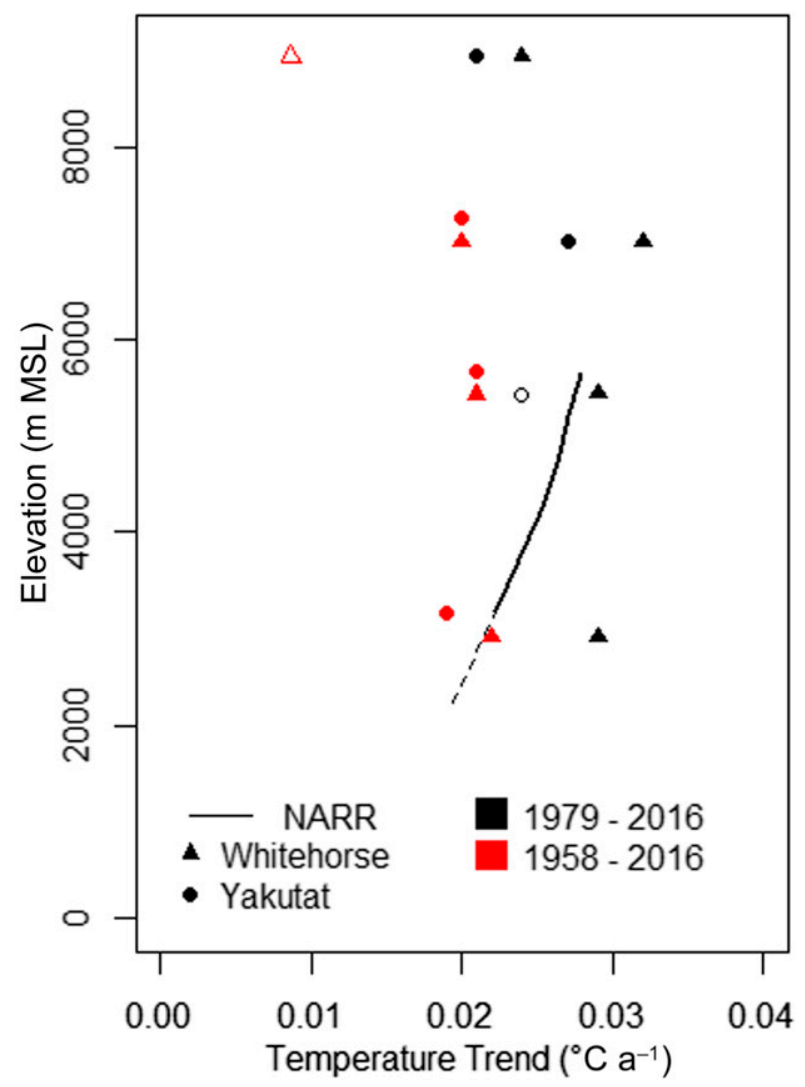

FIG. 6. Temperature trends for annual NARR (line) and radiosonde air temperatures from Whitehorse (triangles) and Yakutat (circles) between 1958 and 2016 (red) and between 1979 and 2016 (black). Closed symbols and the solid line are trends that are significant at $p<0.05$. Open symbols and dashed line are significant at $p<0.10$. Radiosonde temperature trends originate from 1200 UTC time at the 300-, 400-, 500-, and 700-hPa pressure levels (symbols from top to bottom). 1958-2016 Yakutat radiosonde circle symbols have been raised by an offset of $250 \mathrm{~m}$ to prevent overlap with the Whitehorse symbols. The values and standard errors for the points displayed here are found in Tables 2 and 3.

Rossby wave (Winski et al. 2018), pointing to a remote influence on high-altitude summer temperatures in southern Alaska. This is supported by a positive trend in accumulation recorded in the Mount Hunter ice core, which parallels the SST trend in the western Pacific since the mid-nineteenth century. Last, the water vapor pressure concentrations are not appreciably different between the Whitehorse and Yakutat radiosondes.

Long-distance advection of oceanic heat via atmospheric moisture transport could plausibly enhance highelevation warming in the St. Elias Mountains, as it does in the Arctic (Naakka et al. 2019). Moore et al. (2002) reported a significant correlation between the PNA and a composite 100-yr-long ice record of winter precipitation from Mount Logan. However, the Moore et al. (2002) record of precipitation is not corroborated by other high-elevation ice cores in the region, including from Mount Logan, which raises doubts about the significance of the reported PNA correlation (Zdanowicz et al. 2014). Here, the PNA index does not show statistically significant correlations to NARR temperatures at elevations above $3500 \mathrm{~m}$ at the annual time step, indicating that this index is not particularly informative in describing EDW trends. The adjusted $R^{2}$ values for the multiple linear correlations between NARR and Niño + PNA range between 0.05 and 0.13 , and none was significant at the $p<0.05$ level. The low levels of explanatory power that climate indices and ocean temperature have on regional temperature in and around the St. Elias Mountains indicate that these metrics are too coarse to define causal mechanisms for EDW. However, the relatively short length of the NARR time series used here (38 years) suggests that the short time series length is, at least partially, responsible for the lack of significance.

\section{a. Possible causal mechanisms of EDW in the St. Elias Mountains}

In light of the evidence for EDW in the St. Elias Mountains, we compare and contrast evidence that supports or discounts the driving mechanisms outlined in the introduction.

\section{1) SNOW ALBEDO FEEDBACK}

Two lines of evidence indicate that SAF is not substantially influencing the EDW in the St. Elias Mountains. First, both the downscaled NARR data and the radiosonde measurements suggest that the fastest warming since 1979 is occurring $\sim 1000 \mathrm{~m}$ above the Mount Logan Plateau in the free atmosphere. The surface air temperature on the Mt. Logan Plateau ranges between $\sim-48^{\circ}$ and $-4^{\circ} \mathrm{C}$ annually, averaging $\sim-25^{\circ} \mathrm{C}$ (data from station 15; Table 1). At such low temperatures, albedo changes due to temperature variations are small because both snowmelt and snow metamorphism are negligible. In addition, reported concentrations of lightabsorbing particles in snow, such as dust and black carbon, at these elevations are too low to have a major effect on the snow albedo (Holdsworth et al. 1996; Zdanowicz et al. 2006). Second, above $3000 \mathrm{~m}$ the melt-season albedo has not decreased between 2000 and 2016 as would be expected with SAF. Maximum snow accumulation in the St. Elias peaks at elevations in the $2500-3000-\mathrm{m}$ range. Above this main surface level of the icefields, the rate of snowfall decreases as elevation increases into the colder and drier midtroposphere. Discrepancies between water accumulation rates in the ice cores in the St. Elias Mountains are not able to corroborate the increases in atmospheric water vapor pressure with a corresponding 
increase in precipitation. Although snow line changes have been correlated with EDW at lower latitudes, this mechanism does not seem to be responsible for EDW in the St. Elias. Williamson et al. (2018) showed that spring snow-cover variation does not influence air temperature in the southwest Yukon below $3000 \mathrm{~m}$.

A trend toward increasing precipitation in the St. Elias Mountains over the last several hundred years has been suggested from analysis of the 5340-m Prospector-Russel Mount Logan ice core (Moore et al. 2002). This proposed increase in precipitation is correlated with warming of the troposphere measured at the $500-\mathrm{hPa}$ level. However, the suggested increase in precipitation is not well corroborated by other ice cores extracted from the St. Elias Mountains [for a detailed review see Zdanowicz et al. (2014)], indicating that the significance of the recent snow accumulation trend is unresolved.

\section{2) Aerosol Radiative FORCing}

Direct observations of atmospheric aerosol loadings or optical depth over the study region are too scarce to resolve long-term trends (Hsu et al. 2012). Herman et al. (2013) analyzed global trends in satellite measurements of UV reflectivity of Earth's atmosphere at $340 \mathrm{~nm}$ over the period 1979-2011. Their data show evidence of decreasing reflectivity over much of the northwestern North American landmass, suggesting a declining cloud and aerosol cover in the past 30 years. This would likely result in increased spring/summer insolation heating at the surface, but it is unclear as to how much of this reduction is related to aerosols versus cloud cover. A recent modeling study has shown that reductions of sulfate aerosols in Europe since the 1980s are responsible for an additional $0.3 \mathrm{~W} \mathrm{~m}^{-2}$ of forcing, which translates to a warming of $0.5^{\circ} \mathrm{C}$ in the Arctic (Acosta Navarro et al. 2016). The region of warming includes the southwest Yukon. Indirect information on aerosol trends in the study region is provided from ice cores drilled in the St. Elias Icefields (Zdanowicz et al. 2014, and references therein). Of particular interest are records of non-sea-salt sulfate (nssSO ${ }_{4}^{2-}$ ) deposition in snow, as these aerosols scatter incoming shortwave radiation. Cores drilled at Eclipse Icefield ( $3015 \mathrm{~m}$ MSL) and on the Mount Logan plateau $(5340 \mathrm{~m})$ between 1996 and 2002 show slightly declining nssSO ${ }_{4}^{2-}$ concentrations or fluxes in snow since the $\sim 1970$ s to 1980s (Fig. 7), but these interdecadal trends are not statistically significant $(p>0.05)$. In view of this, it seems unlikely that changes in atmospheric $\mathrm{nssSO}_{4}^{2-}$ have contributed much to recent EDW in the St. Elias Mountains.

\section{3) Clouds}

Cloud cover plays a significant role in daytime and nighttime net surface radiation, although through different
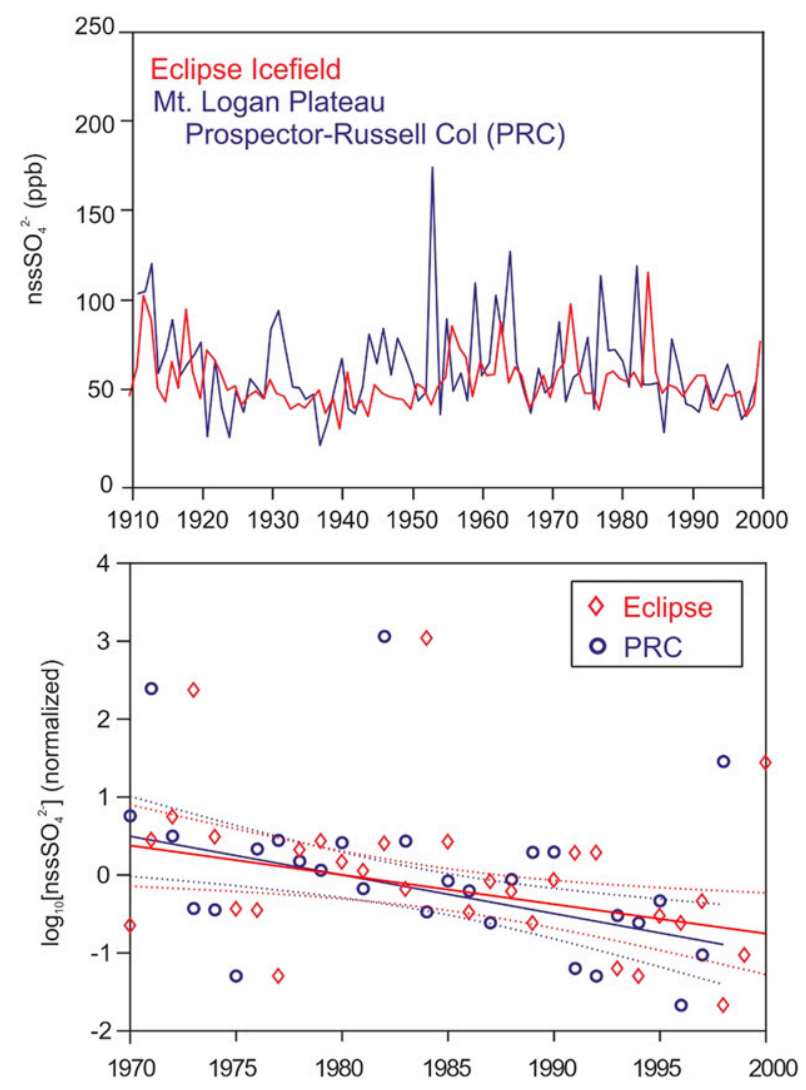

FIG. 7. (top) Ice core records of annually averaged concentrations of non-sea-salt sulfate ( $\mathrm{nsSO}_{4}^{2-}$ ) from Eclipse Icefield (3015 m MSL) and the Mt. Logan Plateau (PRC; $5340 \mathrm{~m} \mathrm{MSL).}$ The Eclipse record is a stacked average from three separate cores. (bottom) Enlargement showing declining trends (robust least squares fit) in $\mathrm{nssSO}_{4}^{2-}$ after 1970 . The $\mathrm{nssSO}_{4}^{2-}$ data were logtransformed and normalized to facilitate comparison of trends at Eclipse and PRC. Dotted lines are $95 \%$ confidence bounds on the regression lines.

mechanisms. It is clear that higher elevations receive substantially more incoming solar radiation than lower elevations because of scattering and absorption in the atmospheric column and absorption and reflection by increasing cloud optical depth with increasing atmospheric column depth. At high elevation (i.e., $>5000 \mathrm{~m}$ ) optically thin stratiform cloud conditions have been shown to increase solar radiation measured at $\sim 5400 \mathrm{~m}$ on Mount Logan due to diffusion and reflection of shortwave radiation (Marcus and LaBelle 1970). Downwelling longwave flux is expected to be less at high elevation because the absolute temperature of the atmosphere is much lower and its mass is less. However, with the exception of Marcus and LaBelle (1970), no measurements of radiation balance in the zone of significant temperature increase (i.e., $>3000 \mathrm{~m}$ ) have been made in the study area. Lack of calibration between remote sensing measures of clouds and surface energy balance in the study area renders 
further comment on the influence of change in clouds on surface temperature speculative.

\section{4) LONGWAVE WATER VAPOR FEEDBACK AND ITS RELATION TO NARR TRENDS}

The climate of the St. Elias Mountains is strongly influenced by advection of Pacific air by westerlies, and could therefore experience differential warming with elevation if this import of moist air acts to increase downwelling longwave radiation at high altitudes (Kotlarski et al. 2012; Vuille et al. 2015; Walton et al. 2015). In support of this, the time series of radiosonde measurements from Yakutat and Whitehorse show some statistically significant increases in water vapor pressure that parallel rising radiosonde and NARR air temperatures, especially since 1979 (Table 3). The larger temperature sensitivity to water vapor at high elevation (e.g., Rangwala 2013) suggests that the water vapor feedback is playing an influential role in EDW at high elevation in the St. Elias Mountains, despite larger absolute increases in water vapor at lower elevation.

\section{5) TROPOSPHERIC WARMING}

Our analysis of the downscaled NARR temperature data show that the contemporary warming rates in the St. Elias Mountains are not limited to elevations below the 800 -hPa pressure level, unlike what most climate models predict for mid- to high latitudes in the Northern Hemisphere (e.g., Pepin et al. 2015). Maximum atmospheric warming at $400 \mathrm{hPa}$ in the St. Elias Mountains also resembles the predicted maximum warming signal between 200 and $400 \mathrm{hPa}$ for low latitudes (Collins et al. 2013). This warming could be related to a decrease in the free-tropospheric lapse rate in a warming climate, which influences ascending saturated air parcels. In principle, this process should be most effective in the tropics where ascending saturated air parcels are more common. However, a recent study suggests that the lapse-rate feedback might be important for Arctic temperature change (Hwang et al. 2018), indicating further study of this topic is required.

\section{Conclusions}

The estimated mean rate of surface warming at elevations of $5500-6000 \mathrm{~m}$ in the St. Elias Mountains was $0.029^{\circ} \mathrm{Ca}^{-1}$ between 1979 and 2016 . This is $\sim 1.5$ times larger than the rate of surface warming between 2000$2500 \mathrm{~m}$ over the same period, and $\sim 1.6$ times larger than the global surface average. This high-elevation surface warming rate in the St. Elias Mountains $(>5500 \mathrm{~m})$ also closely matches warming rates in the free troposphere $(>\sim 3000 \mathrm{~m})$ inferred from radiosoundings close to the study region. Radiosonde data also show that free troposphere warming is largest $\sim 1000 \mathrm{~m}$ above the highest peaks in the St. Elias Mountains. The recent warming is associated with increases in atmospheric water vapor pressure, suggesting that a positive longwave radiation feedback effect contributes to the EDW in this region. Comparison of the downscaled NARR and radiosonde data also show that high-elevation warming in the St. Elias Mountains increased in recent decades, and this acceleration is consistent with warming patterns reported in the Arctic and in midlatitude high mountain ranges.

To clarify the mechanisms driving EDW in the St. Elias Mountains, meteorological stations that measure a full suite of climate variables, in particular atmospheric moisture and surface radiation balance, must be established at the highest elevations that are logistically feasible. An analysis of midtroposphere moisture advection trends and patterns in the North Pacific may also help to clarify the possible role played by oceanic forcing.

Acknowledgments. Financial support for this project was provided by the Canada Foundation for Innovation, the Canada Research Chairs Program, the University of Ottawa, Natural Sciences and Engineering Research Council of Canada (NSERC) Discovery and Northern Research Supplement grants, the National Geographic Society (Washington, DC), and the Geophysical Institute, University of Alaska, Fairbanks. The Natural Sciences and Engineering Research Council of Canada and the Garfield Weston Foundation provided postdoctoral fellowships to S. Williamson.

Author contributions. SNW provided experimental design, manuscript writing, and air temperature measurements; SNW and CZ provided data analysis; FSA, GKCC, and AHJ generated downscaled NARR air temperature; LC, RKD, GEF, DSH, GH, and CZ contributed air temperature measurements. All authors contributed to writing and editing of the manuscript.

\section{REFERENCES}

Acosta Navarro, J. C., and Coauthors, 2016: Amplification of Arctic warming by past air pollution reductions in Europe. Nat. Geosci., 9, 277-281, https://doi.org/10.1038/ngeo2673.

Blackmon, M. L., 1976: Climatological spectral study of $500 \mathrm{mb}$ geopotential height of Northern Hemisphere. J. Atmos. Sci., 33, 1607-1623, https://doi.org/10.1175/1520-0469(1976)033<1607: ACSSOT $>2.0 . \mathrm{CO} ; 2$.

Bradley, R. S., F. T. Keimig, and H. F. Diaz, 2004: Projected temperature changes along the American cordillera and the planned GCOS network. Geophys. Res. Lett., 31, L16210, https://doi.org/10.1029/2004GL020229.

Burn, C. R., 1994: Permafrost, tectonics, and past and future regional climate change, Yukon and adjacent Northwest 
Territories. Can. J. Earth Sci., 31, 182-191, https://doi.org/ 10.1139/e94-015.

Bye, J., K. Fraedrich, E. Kirk, S. Schubert, and X. Zhu, 2011: Random walk lengths of about 30 years in global climate. Geophys. Res. Lett., 38, L05806, https://doi.org/10.1029/ 2010 GL046333.

Chen, B., W. C. Chao, and X. Liu, 2003: Enhanced climatic warming in the Tibetan Plateau due to doubling $\mathrm{CO}_{2}$ : A model study. Climate Dyn., 20, 401-413, https://doi.org/10.1007/ s00382-002-0282-4.

Collins, M., and Coauthors, 2013: Long-term climate change: Projections, commitments and irreversibility. Climate Change 2013: The Physical Science Basis, T. F. Stocker et al., Eds., Cambridge University Press, 1029-1136.

Daly, C., M. Halbleib, J. I. Smith, W. P. Gibson, M. K. Doggett, G. H Taylor, J. Curtis, and P. A. Pasteris, 2008: Physiographically sensitive mapping of climatological temperature and precipitation across the conterminous United States. Int. J. Climatol. 28, 2031-2064, https://doi.org/10.1002/joc.1688.

Duan, A., and G. X. Wu, 2006: Change of cloud amount and the climate warming on the Tibetan Plateau. Geophys. Res. Lett., 33, L22704, https://doi.org/10.1029/2006GL027946.

Elliott, W. P., R. J. Ross, and W. H. Blackmore, 2002: Recent changes in NWS upper-air observations with emphasis on changes from VIZ to Vaisala radiosondes. Bull. Amer. Meteor. Soc., 83, 1003-1017, https://doi.org/10.1175/1520-0477(2002) 083<1003:RCINUA $>2.3$.CO;2.

Fisher, D. A., and Coauthors, 2004: Stable isotope records from Mount Logan, Eclipse ice cores and nearby Jellybean Lake. Water cycle of the North Pacific over 2000 years and over five vertical kilometers: Sudden shifts and tropical connections. Geogr. Phys. Quat., 58, 337-352, https://doi.org/10.7202/ 013147AR

—_, and Coauthors, 2008: The Mt Logan Holocene-late Wisconsinan isotope record: Tropical Pacific-Yukon connections. Holocene, 18, 667-677, https://doi.org/10.1177/ 0959683608092236

Fliri, F., 1971: Neue klimatologische Querprofile der Alpen-Ein Energiehaushalt. Ann. Meteor., 5, 93-97.

Frierson, D. M. W., 2006: Robust increases in midlatitude static stability in simulations of global warming. Geophys. Res. Lett., 33, L24816, https://doi.org/10.1029/2006GL027504.

Fyfe, J. C., and J. M. Flato, 1999: Enhanced climate change and its detection over the Rocky Mountains. J. Climate, 12, 230-243, https://doi.org/10.1175/1520-0442-12.1.230.

Giorgi, F., J. W. Hurrell, M. R. Marinucci, and M. Beniston, 1997: Elevation dependency of the surface climate change signal: A model study. J. Climate, 10, 288-296, https://doi.org/10.1175/ 1520-0442(1997)010<0288:EDOTSC > 2.0.CO;2.

Hall, A., and S. Manabe, 1999: Role of water vapor feedback in unperturbed climate variability and global warming. J. Climate, 12, 2327-2346, https://doi.org/10.1175/1520-0442(1999) $012<2327$ :TROWVF $>2.0 . \mathrm{CO} ; 2$.

Hall, D. K., G. A. Riggs, V. V. Salomonson, N. E. DiGirolamo, and K. J. Bayd, 2002: MODIS snow-cover products. Remote Sens. Environ., 83, 181-194, https://doi.org/10.1016/S0034-4257(02) 00095-0.

Held, I. M., and B. J. Soden, 2000: Water vapor feedback and global warming. Annu. Rev. Environ. Resour., 25, 441-475, https:// doi.org/10.1146/annurev.energy.25.1.441.

Herman, J., M. T. DeLand, L.-K. Huang, G. Labow, S. A. Lloyd, J. Mao, W. Qin, and C. Weaver, 2013: A net decrease in the Earth's cloud, aerosol, and surface $340 \mathrm{~nm}$ reflectivity during the past 33 yr (1979-2011). Atmos. Chem. Phys., 13, 85058524, https://doi.org/10.5194/acp-13-8505-2013.

Hik, D. S., and S. N. Williamson, 2019: Need for mountain weather stations climbs. Science, 366, 1083, https://doi.org/10.1126/ science.aaz7450.

Holdsworth, G., and Coauthors, 1996: Historical biomass burning: Late 19th century pioneer agriculture revolution in Northern Hemisphere ice core data and its atmospheric interpretation. J. Geophys. Res., 101, 23 317-23 334, https://doi.org/10.1029/ 96JD01158.

Hsu, N. C., R. Gautam, A. M. Sayer, C. Bettenhausen, C. Li, M. J. Jeong, S.-C. Tsay, and B. N. Holben, 2012: Global and regional trends of aerosol optical depth over land and ocean using SeaWiFS measurements from 1997 to 2010. Atmos. Chem. Phys., 12, 8037-8053, https://doi.org/10.5194/acp12-8037-2012.

Hwang, J., Y.-S. Choi, W. Kim, H. Su, and J. H. Jiang, 2018: Observational estimation of radiative feedback to surface air temperature over northern high latitudes. Climate Dyn., 50, 615-628, https://doi.org/10.1007/s00382-017-3629-6.

Jarosch, A. H., F. S. Anslow, and G. K. C. Clarke, 2012: Highresolution precipitation and temperature downscaling for glacier models. Climate Dyn., 38, 391-409, https://doi.org/ 10.1007/s00382-010-0949-1.

Klein, A. G., and J. Stroeve, 2002: Development and validation of a snow albedo algorithm for the MODIS instrument. Ann. Glaciol., 34, 45-52, https://doi.org/10.3189/ 172756402781817662

Kotlarski, S., T. Bosshard, D. Lüthi, P. Pall, and C. Schär, 2012: Elevation gradients of European climate change in the regional climate model COSMO-CLM. Climatic Change, 112, 189-215, https://doi.org/10.1007/s10584-011-0195-5.

Lawrimore, J. H., M. J. Menne, B. E. Gleason, C. N. Williams, D. B. Wuertz, R. S. Vose, and J. Rennie, 2011: An overview of the Global Historical Climatology Network monthly mean temperature data set, version 3. J. Geophys. Res., 116, D19121, https://doi.org/10.1029/2011JD016187.

Liu, X., Z. Cheng, L. Yan, and Z.-Y. Yin, 2009: Elevation dependency of recent and future minimum surface air temperature trends in the Tibetan Plateau and its surroundings. Global Planet. Change, 68, 164-174, https://doi.org/10.1016/ j.gloplacha.2009.03.017.

Marcus, M. G., and J. R. LaBelle, 1970: Summer climate observations at the 5,360 meter level, Mt. Logan, Yukon: 19681969. Arct. Antarct. Alp. Res., 2, 103-114, https://doi.org/ $10.2307 / 1550346$.

Mesinger, F., and Coauthors, 2006: North American Regional Reanalysis. Bull. Amer. Meteor. Soc., 87, 343-360, https:// doi.org/10.1175/BAMS-87-3-343.

Mesquita, M. S., D. E. Atkinson, and K. I. Hodges, 2010: Characteristics and variability of storm tracks in the North Pacific, Bering Sea, and Alaska. J. Climate, 23, 294-311, https://doi.org/10.1175/2009JCLI3019.1.

Moore, G. W. K., G. Holdsworth, and K. Alverson, 2002: Climate change in the North Pacific region over the past three centuries. Nature, 420, 401-403, https://doi.org/10.1038/nature01229.

Naakka, T., T. Nygård, T. Vihma, J. Sedlar, and R. Graversen, 2019: Atmospheric moisture transport between mid-latitudes and the Arctic: Regional, seasonal and vertical distributions. Int. J. Climatol., 39, 2862-2879, https://doi.org/10.1002/joc.5988.

NOAA, 2016: State of the climate: Global climate report for annual 2015. National Oceanic and Atmospheric Administration (NOAA) National Centers for Environmental Information 
(NCEI), accessed 15 January 2020, www.ncdc.noaa.gov/sotc/ global/201513.

Osborne, E., J. Richter-Menge, and M. Jeffries, Eds., 2018: Arctic report card 2018. NOAA, 110 pp., https://www.arctic.noaa.gov/ Report-Card.

Osterberg, E. C., P. A. Mayewski, D. A. Fisher, K. J. Kreutz, K. A. Maasch, S. B. Sneed, and E. Kelsey, 2014: Mount Logan ice core record of tropical and solar influences on Aleutian low variability: 500-1998 A.D. J. Geophys. Res. Atmos., 119, 11 189-11 204, https://doi.org/10.1002/2014JD021847.

_ - and Coauthors, 2017: The 1200 year composite ice core record of Aleutian low intensification. Geophys. Res. Lett., 44, 7447-7454, https://doi.org/10.1002/2017GL073697.

Oyler, J. W., S. Z. Dobrowski, A. P. Ballantyne, A. E. Klene, and S. W. Running, 2015: Artificial amplification of warming trends across the mountains of the western United States. Geophys. Res. Lett., 42, 153-161, https://doi.org/10.1002/ 2014GL062803.

Palazzi, E., L. Filippi, and J. von Hardenberg, 2017: Insights into elevation dependent warming in the Tibetan PlateauHimalayas from CMIP5 model simulations. Climate Dyn., 48, 3991-4008, https://doi.org/10.1007/S00382-016-3316-Z.

, L. Mortarini, S. Terzago, and J. von Hardenberg, 2018: Elevation-dependent warming in global climate model simulations at high spatial resolution. Climate Dyn., 52, 2685-2702, https://doi.org/10.1007/s00382-018-4287-z.

Pepin, N. C., and D. J. Seidel, 2005: A global comparison of surface and free-air temperatures at high elevations. J. Geophys. Res., 110, D03104, https://doi.org/10.1029/2004JD005047. , and J. D. Lundquist, 2008: Temperature trends at high elevations: Patterns across the globe. Geophys. Res. Lett., 35, L14701, https://doi.org/10.1029/2008GL034026.

_- and Coauthors, 2015: Elevation-dependent warming in mountain regions of the world. Nat. Climate Change, 5, 424430, https://doi.org/10.1038/nclimate2563.

Porter, T. J., S. W. Schoenemann, L. J. Davies, E. J. Steig, S. Bandara, and D. G. Froese, 2019: Recent summer warming in the northwestern Canada exceeds the Holocene thermal maximum. Nat. Commun., 10, 1631, https://doi.org/10.1038/ s41467-019-09622-y.

Qin, J., K. Yang, S. Liang, and X. Guo, 2009: The altitudinal dependence of recent rapid warming over the Tibetan Plateau. Climatic Change, 97, 321-327, https://doi.org/10.1007/ S10584-009-9733-9.

Ramanathan, V., and G. Carmichael, 2008: Global and regional climate changes due to black carbon. Nat. Geosci., 1, 221-227, https://doi.org/10.1038/ngeo156.

Rangwala, I., 2013: Amplified water vapour feedback at high altitudes during winter. Int. J. Climatol., 33, 897-903, https:// doi.org/10.1002/joc.3477.

, J. R. Miller, and M. Xu, 2009: Warming in the Tibetan Plateau: Possible influences of the changes in surface water vapor. Geophys. Res. Lett., 36, L06703, https://doi.org/10.1029/ 2009GL037245.

, - _ G. L. Russell, and M. Xu, 2010: Using a global climate model to evaluate the influences of water vapor, snow cover and atmospheric aerosol on warming in the Tibetan Plateau during the twenty-first century. Climate Dyn., 34, 859-872, https://doi.org/10.1007/s00382-009-0564-1.

, E. Sinsky, and J. R. Miller, 2016: Variability in projected elevation dependent warming in boreal midlatitude winter in CMIP5 climate models and its potential drivers. Climate Dyn., 46, 2115-2122, https://doi.org/10.1007/s00382-015-2692-0.
Ruckstuhl, C., R. Philipona, J. Morland, and A. Ohmura, 2007: Observed relationship between surface specific humidity, integrated water vapor, and longwave downward radiation at different altitudes. J. Geophys. Res., 112, D03302, https:// doi.org/10.1029/2006JD007850.

Rupp, D. E., S. Li, P. W. Mote, K. M. Shell, N. Massey, S. N. Sparrow, D. C. H. Wallom, and M. R. Allen, 2017: Seasonal spatial patterns of projected anthropogenic warming in complex terrain: A modeling study of the western US. Climate Dyn., 48, 2191-2213, https://doi.org/10.1007/s00382016-3200-x.

Salathé, E. P., Jr., R. Steed, C. F. Mass, and P. H. Zahn, 2008: A high resolution climate model for the U.S. Pacific Northwest: Mesoscale feedbacks and local responses to climate change. J. Climate, 21, 5708-5726, https://doi.org/ 10.1175/2008JCLI2090.1.

Serreze, M., and R. G. Barry, 2011: Processes and impacts of Arctic amplification: A research synthesis. Global Planet. Change, $\mathbf{7 7}$, 85-96, https://doi.org/10.1016/j.gloplacha.2011.03.004.

_ A. Barrett, J. Stroeve, D. Kindig, and M. Holland, 2009: The emergence of surface-based Arctic amplification. Cryosphere, 3, 11-19, https://doi.org/10.5194/tc-3-11-2009.

Smirnov, V. V., and G. W. K. Moore, 1999: Spatial and temporal structure of atmospheric water vapor transport in the Mackenzie River basin. J. Climate, 12, 681-696, https://doi.org/10.1175/15200442(1999)012<0681:SATSOA > 2.0.CO;2.

Stroeve, J., J. E. Box, and T. Haran, 2006: Evaluation of the MODIS (MO10A1) daily snow albedo product over the Greenland ice sheet. Remote Sens. Environ., 105, 155-171, https://doi.org/10.1016/J.RSE.2006.06.009.

Vuille, M., E. Franquist, R. Garreaud, W. S. Lavado Casimiro, and B. Cáceres, 2015: Impact of the global warming hiatus on Andean temperature. J. Geophys. Res. Atmos., 120, 37453757, https://doi.org/10.1002/2015JD023126.

Wahl, H. E., D. B. Fraser, R. C. Harvey, and J. B. Maxwell, 1987: Climate of Yukon, Vol. 40, Canada Atmospheric Environment Service Climatological Studies. Environment Canada, 323 pp.

Wallace, J. M., and D. S. Gutzler, 1981: Teleconnections in the geopotential height field during the Northern Hemisphere winter. Mon. Wea. Rev., 109, 784-812, https://doi.org/10.1175/ 1520-0493(1981)109<0784:TITGHF > 2.0.CO;2.

Walton, D. B., F. Sun, A. Hall, and S. Capps, 2015: A hybrid dynamical-statistical downscaling technique. Part I: Development and validation of the technique. J. Climate, 28, 4597-4617, https:// doi.org/10.1175/JCLI-D-14-00196.1.

Wang, Q., X. Fan, and M. Wang, 2014: Recent warming amplification over high elevation regions across the globe. Climate Dyn., 43, 87-101, https://doi.org/10.1007/s00382-013-1889-3.

,-- , and - 2016: Evidence of high-elevation amplification versus Arctic amplification. Sci. Rep., 6, 19219, https:// doi.org/10.1038/srep19219.

Williamson, S. N., L. Copland, and D. S. Hik, 2016: The accuracy of satellite-derived albedo for northern alpine and glaciated land covers. Polar Sci., 10, 262-269, https://doi.org/10.1016/ j.polar.2016.06.006.

, D. S. Hik, J. A. Gamon, A. H. Jarosch, F. S. Anslow, G. K. C. Clarke, and S. Rupp, 2017: Spring and summer monthly MODIS LST is inherently biased compared to air temperature in snow covered sub-Arctic mountains. Remote Sens. Environ., 189, 14-24, https://doi.org/10.1016/j.rse.2016.11.009. , F. S. Anslow, G. K. C. Clarke, J. A. Gamon, A. H. Jarosch, and D. S. Hik, 2018: Spring warming in Yukon mountains is 
not amplified by snow albedo feedback. Sci. Rep., 8, 9000, https://doi.org/10.1038/s41598-018-27348-7.

Winski, D., and Coauthors, 2017: Industrial-age doubling of snow accumulation in the Alaska Range linked to tropical ocean warming. Sci. Rep., 7, 17869, https://doi.org/10.1038/S41598-017-18022-5.

__ , and Coauthors, 2018: A 400-year ice core melt layer record of summertime warming in the Alaska Range. J. Geophys. Res. Atmos., 123, 3594-3611, https://doi.org/10.1002/2017JD027539.

Yan, L., Z. Liu, G. Chen, J. E. Kutzbach, and X. Liu, 2016: Mechanisms of elevation-dependent warming over the Tibetan Plateau in quadrupled $\mathrm{CO}_{2}$ experiments. Climatic Change, 135, 509-519, https://doi.org/10.1007/s10584-016-1599-z.

You, Q., S. Kang, N. Pepin, W.-A. Flügel, Y. Yan, H. Behrawan, and J. Huang, 2010: Relationship between temperature trend magnitude, elevation and mean temperature in the Tibetan
Plateau from homogenized surface stations and reanalysis data. Global Planet. Change, 71, 124-133, https://doi.org/ 10.1016/J.GLOPLACHA.2010.01.020.

Zdanowicz, C., G. Hall, J. Vaive, Y. Amelin, J. Percival, I. Girard, P. Biscaye, and A. Bory, 2006: Asian dustfall in the St. Elias Mountains, Yukon, Canada. Geochim. Cosmochim. Acta, 70, 3493-3507, https://doi.org/10.1016/j.gca.2006.05.005.

, and Coauthors, 2014: Ice cores from the St. Elias Mountains, Yukon, Canada: Their significance for climate, atmospheric composition and volcanism in the North Pacific region. Arctic, 67, 35-57, https://doi.org/10.14430/arctic4352.

Zeng, Z., and Coauthors, 2015: Regional air pollution brightening reverses the greenhouse gases induced warming-elevation relationship. Geophys. Res. Lett., 42, 4563-4572, https://doi.org/ 10.1002/2015GL064410. 